\title{
The Role of Nagari Traditional Representative and Bundo Kanduang in Nagari (Village) Development
}

\author{
Rizki Syafril ${ }^{1 *}$, Iip Permana ${ }^{2}$, and Artha Dini $\mathrm{Akmal}^{3}$ \\ ${ }^{123}$ Department of Public Administration, Universitas Negeri Padang, Padang, Indonesia \\ *Corresponding author. Email: rizkisyafril@fis.unp.ac.id
}

\begin{abstract}
Nagari Traditional Representative (KAN) and Bundo Kanduang are Nagari Society Institutions. Is a forum for the participation of the Nagari community which is the partner of the Nagari government. The Nagari government needs the involvement of KAN and Bundo Kanduang in making a policy or decision. KAN and Bundo Kanduang function to assist in the implementation of Nagari development, the method used in this research is descriptive qualitative research with a case study approach. Where this study focuses intensely on one object and learns to be a case. Sampling in the study used purposively, where the informant was chosen directly by the researcher. The results show that KAN and Bundo Kanduang are Nagari Society Institutions that play an important role in the development of the Nagari, quality KAN and Bundo Kanduang determine the goal of Nagari Development, namely to improve people's welfare.
\end{abstract}

Keywords: Nagari Society Institutions, KAN, Bundo Kanduang

\section{INTRODUCTION}

In the general provisions of Regional regulations Agam District 12/2007 concerning Nagari Governance, Nagari Society Institutions are institutions formed by the community according to their needs and are partners of the Nagari government in community empowerment. KAN and Bundo Kanduang are part of the Nagari social institutions.

Specifically for Nagari Panampuang involves the participation of Nagari Social Institutions such as KAN and Bundo Kanduang as partners in the context of organizing government affairs, development, community development, and community empowerment. Nagari Social Institutions in the form of KAN and Bundo Kanduang as implementers of village development and community empowerment as well as administrators of village governance.

About Nagari Panampuang, the roles of KAN and Bundo Kanduang have not shown their functions and duties as partners of the Nagari Panampuang government in terms of village development. KAN and Bundo Kanduang currently only focus on the internal problems of their respective institutions in general, so that the objectives of the development referred to above are very difficult to realize. KAN and Bundo Kanduang, partners of the village government, did not work properly, the structural condition of the management of the institution, which was only a formality requirement, and the lack of awareness of the management of the rights and obligations of the institution in particular and the village in general, resulted in not optimal village development.
The formulation of the problem is what is the role of KAN and Bundo Kanduang in the development of Nagari Panampuang? and What are the factors and impacts of the role of KAN and Bundo Kanduang in the development of Nagari Panampuang?. As to know the role of KAN and Bundo Kanduang in the development of Nagari Panampuang. and knowing the factors and impacts related to the role of IKAN and Bundo Kanduang in the development of Nagari Panampuang.

\section{METHOD}

This research approach uses qualitative research methods. Meanwhile, the type of research is descriptive method. Type of Data used; 1. Primary data in the form of management and members of Nagari social institutions as well as elements of society related to interview techniques and; $b$. Secondary data consists of documents in the form of regulations and legislation and other documents in the form of papers, journals, magazines, and newspapers.

The research location was conducted in Nagari Panampuang, Ampek Angkek District, Agam Regency West Sumatra. Subjects and Data Sources: a. The informants were "Walinagari and Head of Bamus (Nagari Government)" and "Niniak Mamak, Alim Ulama, Cadiak Pandai, Bundo Kanduang, Youth Element and Women's Element (Nagari Society Institutions)" and "Community Leaders and Part of the General Public". b. Events / Phenomena. c. Documents Relevant documents.

Data collection technique; a. Interview; b. Observation; c. Document. Data Analysis Techniques: a. Reduction is data obtained in the field written in the form 
of a detailed description; b. Presentation of data is the result of reduction obtained and displayed in the thesis; $\mathrm{c}$. Verify and conclude.

\section{FINDING AND DISCUSSION}

KAN and Bundo Kanduang are institutions engaged in the field of Cultural Adat, which in the life order of the Nagari Panampuang people always adhere to the teachings of Islam and Adat Istiadat Minangkabau based on the philosophy of Adat Basandi Syara 'Syara' Basandi Kitabullah which means Syara Mangato Adat Mamakai. This can be seen, among others, from the administration of the government and the implementation of development which always uses the way of deliberation and consensus in making decisions by involving all existing elements of society such as Niniak Mamak, Alim Ulama, Cadiak Pandai, Bundo Kanduang and the younger generation accommodated in the Nagari Consultative Body Institution. The existence of the role of Penghulu / Niniak Mamak in encouraging the pace of development, both in the field of security and order, as well as in the field of preservation, understanding and practising the traditional, social and cultural values of Nagari Panampuang, with the philosophy of Adat Basandi Syara'. Syara' Basandi Kitabullah and Kamanakan Saparintah Mamak and Malu Satuntuik Hutang Sabayia.

The legal basis for KAN is Law Number 6 of 2014 concerning Villages in Chapter XII of Village Community Institutions and Village Customary Institutions, the second part of Village Customary Institutions article 95, Regulation of the Minister of Home Affairs Number 5 of 2007 concerning Guidelines for Organizing Social Institutions Chapter IV Types of articles 10 - 11, Regional Regulation of West Sumatra Province Number 2 of 2007 concerning the Principles of Nagari Government Chapter VIII Density of Nagari Adat Article 28-29, and Regional Regulation of Agam Regency Number 12 of 2007 concerning Nagari Government Chapter XI Nagari Social Institutions first part Kerapatan Adat Nagari Article 117 119 and the third part Financing Article 123

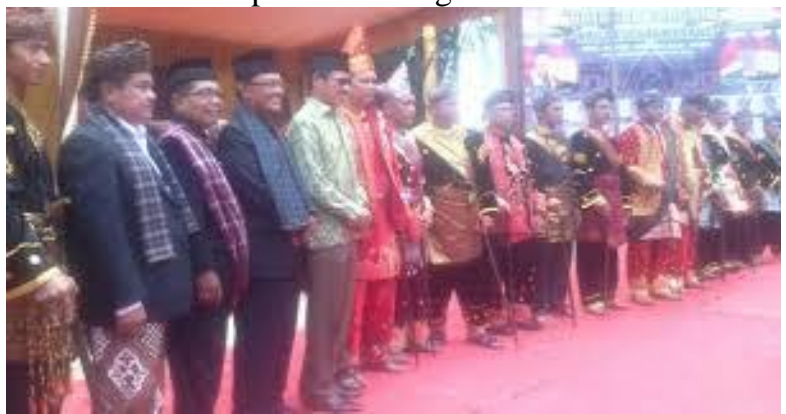

Kerapatan Adat Nagari, hereinafter abbreviated as $\mathrm{KAN}$, is a customary institution that is either deliberately formed or that has naturally grown and developed in the history of society or a certain customary law community with a legal area and rights to assets in that customary law, and has the right and is authorized to regulate, manage and resolve various life problems related to reference to prevailing customs and customary laws.

KAN is the highest institution that has existed and has been inherited from generation to generation as long as it is customary in the midst of the Nagari community, whose membership is following adat Salingka Nagari. KAN Panampuang is an institution that is under the Panampuang Nagari government which focuses on issues of traditional and village culture, so the management of KAN is determined by a decree from Walinagari Panampuang. On the other hand, KAN also has a structured supervisory agency from the sub-district level to the provincial level called Lembaga Kerapatan Adat Alam Minangkabau (LKAAM).

KAN Panampuang whose management is in accordance with adat salingka nagari, whose management must be based on representation in every jorong in the Panampuang village and must be based on several elements, in the form of Niniak Mamak, Alim Ulama, Cadiak Pandai and the younger generation. The election of the chairman and members of the Panampuang KAN is based on deliberation and consensus Datuak "Basa Nan Sapuluah", namely 2 Datuak "Gadang Basuku and Gadang Bahindu" who represent 1 parent tribe from 5 main tribes in the Panampuang village namely the Jambak tribe, the Guci tribe, the Tanjuang tribe, the Koto tribe, and the Sikumbang tribe. In the management of KAN, from the chairman to the member, must come from datuak pucuak consisting of 9 datuak from the jambak tribe, 9 datuak from the guci tribe, 6 datuak from the tanjuang tribe, 6 datuak from the koto tribe and 3 datuak from the sikumbang tribe with a total of 33 datuak from 33 tribes.

Based on the deliberation and consensus agreement with Basa Nan Sapuluah, the management of KAN Panampuang was formed which was later determined by the Walinagari Panampuang decree No. 30 of 2015 concerning the Appointment of the Panampuang Nagari Density Management Committee for the 2015-2021 Period. From the management structure, based on deliberation and consensus Datuak Basa Nan Sapuluah, not all Datuak 33 are still in the management, and from the management, there are 2 Datuak Pucuak who are not from Datuak 33, namely Datuak Rajo Agam and Datuak Sati. In carrying out its functions, KAN Panampuang in realizing community participation is sometimes aristocratic but sometimes it can also be democratic so that the participation of the community in general and customary stakeholders, in particular, is not very clear under certain conditions.

Meanwhile, the legal basis of Bundo Kanduang, namely Law Number 6 of 2014 concerning Villages in Chapter XII of Village Community Institutions and Village Customary Institutions, the first part of Village 
Community Institutions, article 94, Regulation of the Minister of Home Affairs Number 5 of 2007 concerning Guidelines for the Structuring of Social Institutions Chapter IV Types Article 18, and Regional Regulation of Agam Regency Number 12 of 2007 concerning Nagari Government Chapter XI Nagari Social Institutions second part Other Social Institutions Articles 120 - 122 and the third part Financing Article 123.

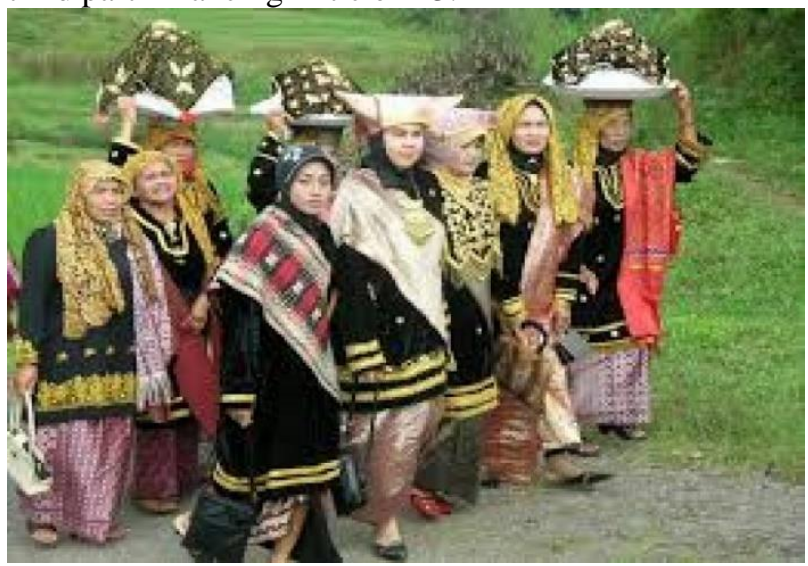

Bundo Kanduang is a customary institution that is either deliberately formed or that has naturally grown and developed in the history of the community or a certain customary law community with a legal territory and rights to property in that customary law and has the right and authority to regulate, administer and solving various life problems related to referring to applicable customs and customary laws, this institution focuses on the role of Minangkabau women.

Bundo Kanduang is an institution that has existed and has been passed down from generation to generation along adat among the Nagari community, whose membership is made up of women according to the adat salingka Nagari. Bundo Kanduang Nagari Panampuang is an institution that is under the Panampuang Nagari government which focuses on the role of Panampuang Nagari women so that the management of Bundo Kanduang is determined by a decree from Walinagari Panampuang Number 27 of 2014 concerning the Inauguration of the Bundo Kanduang Nagari Panampuang Management for the 2014-2020 period.

In carrying out its duties, Bundo Kanduang Nagari Panampuang which is the partner of the Panampuang village government is always accompanied and accompanied by KAN Panampuang and Bundo Kanduang Nagari Panampuang also fostered by Bundo Kanduang sub-districts, districts, and provinces. In this case, the participation of mothers is always focused on issues of custom and culture as well as religious social education of the Nagari community, Bundo Kanduang plays an important role in the implementation of customs but is also very necessary in educating the younger generation in the Puti Bungsu forum.

The duties of KAN and Bundo Kanduang are to assist the Nagari Government in implementing government, development, social, and community affairs and are partners in community empowerment. The tasks referred to include: a. Compiling development plans in a participatory manner; b. Implement, control, utilize, maintain, and develop development in a participatory manner; c. Mobilize and develop participation, cooperation, and community self-help; d. Developing the dynamic conditions of society in the context of community empowerment.

Meanwhile, in carrying out the duties of KAN and Bundo Kanduang, they have the following functions: a. Collecting and channeling the aspirations of the community, including in development; b. planting and fostering a sense of community unity and integrity in the framework of strengthening the Unitary State of the Republic of Indonesia; c. Increasing the quality and acceleration of government services to the community; $d$. To formulate plans, implementers, controllers, and managers of development as well as users of conservation and development of development outcomes in a participatory manner; e. Development and activator of community initiative, participation, and self-help; $f$. Empowerment and improvement of family welfare; $\mathrm{g}$. Empowerment and protection of community political rights; h. digging, exploiting, and developing potential resources as well as environmental harmony; $i$. Development of creativity, prevention of delinquency, abuse of illegal drugs (drugs) for adolescents; $j$. Supporting media for communication, information, and socialization between the village government and the community.

For KAN and Bundo Kanduang, in carrying out their functions, they are divided into 3 elements, namely: first, the administrator who will act as executor in the village government to influence the policies taken. Second, the community will serve as spectators or as observers who will later serve as an assessment, whether the KAN and Bundo Kanduang administrators can influence village government policies and as beneficiaries of the results of activities that are beneficial to the community. Meanwhile, the third member of the KAN and Bundo Kanduang has a double position. As an extension of the management of KAN and Bundo Kanduang in carrying out their functions, then they play a role by mingling with society in implementing Nagari Panampuang government policies.

KAN has the task of helping the Nagari Panampuang government and as a partner for empowerment, fostering and preserving culture and customs as a form of recognition of the customs of the 
village community and the relationship between traditional leaders and the Nagari Government. The duties of KAN include a. To approve changes to the status and function of village assets; $b$. Ward off the entry of cultural influences that destroy customary values; c. Resolve customary civil cases related to Sako, Pusako, and Sangsako; d. Giving a certificate to someone regarding the implementation of the applicable customary provisions; e. Approve cooperation in the management of village wealth with third parties; $f$. Take an active role in every development in the village as a working partner for the village government; g. Take care of and manage matters related to adat, Sako, and Pusako; h. Cooperate with other Nagari institutions in resolving social, cultural, and religious problems;

KAN in carrying out its duties has the following functions: a. Collecting and channeling community opinions or aspirations to the Nagari Government and resolving disputes concerning customary law, customs, and community habits; b. Empowerment, preservation, and development of the customs and habits of the community in the framework of enriching the culture of the community and empowering the community in supporting the implementation of Nagari Government, implementing development and community guidance; c. Creation of a democratic and harmonious and objective relationship between the customary head / customary leader / customary leader or traditional leader and Nagari Government officials; d. Maintain and enforce the Minangkabau customary values; e. Encouraging the implementation of community life based on the Salingka Nagari custom; f. Fostering Pangatuo and Anak Mudo Kampuang as well as village communities according to the Adat Basandi Syara, Syara' Basandi Kitabullah; g. Improve the quality and role of customary stakeholders in the Nagari; h. Passing Minangkabau customary values to nephews; f. as an adhesive for the relationship between functional groups and the Nagari people in the empowerment of Sako, Pusako, and Sangsako.

In the implementation of functions, KAN highly prioritizes the hierarchy of political participation from the management, members, and the community, both the functions that must be carried out by KAN as described above and also efforts to influence the policies of the Nagari Panampuang government related to Nagari Panampuang customs issues. However, in the implementation of the KAN's function and efforts to influence village government policies, it is very dominant that only the core management is carried out, while members are only waiting and the community tends to be apathetic.

Bundo Kanduang has the task of helping the Nagari Panampuang government and as a partner in empowering, fostering, and preserving culture and customs as a form of recognition of the customs of the Nagari community. As a place to imitate, exemplary, and educate all family members in society, as well as a driving force for the family and community economic resources

Bundo Kanduang in carrying out its duties has the following functions: a. To accommodate and channel public opinion to the Nagari Government concerning the customs, customs, and habits of the community; $b$. Empowerment, preservation, and development of the customs and habits of the community in the framework of enriching the culture of the community and empowering the community in supporting the implementation of Nagari Government, implementing development and community guidance; $\mathrm{c}$. The creation of a democratic and harmonious and objective relationship between the community and the Nagari government officials; $d$. Maintain and enforce the Minangkabau customary values; e. Encouraging the implementation of community life based on the Salingka Nagari custom; f. fostering the village community according to the adat Basandi Syara, Syara' Basandi Kitabullah; g. To improve the quality and role of Bundo Kanduang in the village; h. Passing Minangkabau customary values to nephews; i. As an adhesive for the relationship between functional groups and the village people in empowering the village community; j. Fostering and mobilizing the Bundo Kanduang institutions in Jorong and the youngest women's institution in the Nagari.

In the implementation of its functions, Bundo Kanduang prioritizes the hierarchy of political participation of the management, members, and the community, both the functions that must be carried out by the Kanduang Bundo as described above and also efforts to influence the policies of the Nagari Panampuang government related to customs issues. as well as fostering and empowering families and communities of Nagari Panampuang. However, in the implementation of the Kanduang Bundo function and efforts to influence the policy of the village government, it is very dominant that it is only carried out by the core management, while members are only waiting and the community tends to be apathetic to the function of the Bundo Kanduang Nagari.

Community participation in the form of involvement in KAN and Bundo Kanduang, both as a committee member and as a member. In the context of Nagari Panampuang, there is quite a lot of management personnel in KAN and Bundo Kanduang, KAN has 27 administrators while Bundo Kanduang has 22 administrators.

So many management personnel of KAN and Bundo Kanduang plus members have represented all elements of society such as Niniak Mamak, Alim Ulama, Cadiak Pandai, representatives of women and the young generation as well as community leaders, and also in the 
form of representation in every Jorong-Jorong in Nagari Panampuang. With the existence of management and members at KAN and Bundo Kanduang, it has been proven that there is an activity even though it is at different levels.

Several views can be obtained: 1) all management and members of KAN and Bundo Kanduang are only visible at the time of the formation of the board, meanwhile in general, in practice, KAN and Bundo Kanduang are only run by 2-3 administrators, administrators, and members. others are not active. 2) KAN and Bundo Kanduang do not have a clear work program and do not have views/direction in institutions, besides that KAN and Bundo Kanduang never hold internal meetings between management and members, so that the management and members are never coordinated and subsequently do not give influence on society "

In the phenomenon that occurs in the form of many management and institutional members, it cannot guarantee that it can contribute to the management and members in particular and the general public in Nagari Panampuang. Participation in institutions is very high when a large number of people are joined and involved, while carrying out institutional functions, participation is not very visible except only by the core management who are always active in influencing policies in the Nagari Panampuang government.

KAN and Bundo Kanduang have not optimally carried out their duties and functions as institutions, because this is thought to be caused by several factors, as follows:

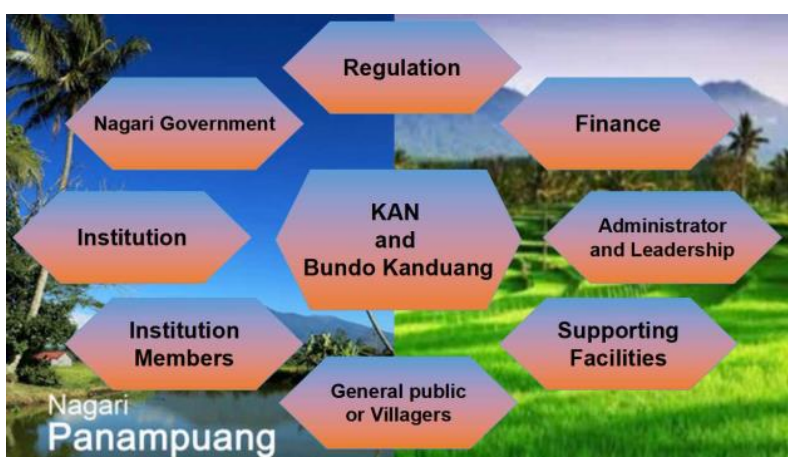

First, KAN and Bundo Kanduang have not and are not carrying out their functions as partners of the Panampuang Nagari Government. There are still many lists of problems that make roles ineffective and dysfunctional. Some of the problems that arise include, the absence of regulations in the form of Nagari Regulations that discuss specifically, so that there is a lack of responsibility for the management in carrying out their duties, work programs that should be clear and directed in this case are not very popular, on a different side the community is less enthusiastic due to coordination between institutions. and the village government and the community did not hit the target.

About the problems that exist, it is very influential and has an impact on community participation consisting of elements of institutional administrators, institutional members, and society in general. List of problems in KAN and Bundo Kanduang, as follows: 1). There are no clear rules relating; 2 ). The role of the management is not maximal in carrying out their duties; 3 ). Less populist work program; 4). Inability to use available facilities and budget; 5). Inactivity of some of the management; 6). Do not have a clear and structured work program; 7). Lack of coordination between social institutions and government; 8). Uncoordinated organizations within the institution; 9). Weak public enthusiasm for social institutions; 10). Lack of supporting infrastructure.

Second, based on the Nagari Panampuang Revenue Budget, before 2015 Nagari social institutions had their budget items in the Nagari APB, meaning whether there were activities or not, the institution had its budget. In 2015, the budget line for institutions was revised, not based on existing institutions, but based on village spending which consists of several fields of activity, namely: the implementation of village development, the field of village community development, and the empowerment of village communities.

The field of activity is based on the work program of social institutions at the time of the preparation of the R-APB Nagari. So, whether the activity is accommodated or not depends on the work program of the institution submitted in the deliberation to ratify the Nagari Panampuang APB. In that sense, if KAN and Bundo Kanduang take part in the deliberations, it is certain to get a budget for the institution and vice versa if they do not. Thus, KAN and Bundo Kanduang in Nagari Panampuang, which should have the functions stated in Law Number 6 of 2014 concerning Villages, in this case, have not and or have not carried out the mandate of the Law.

On the other hand, it is known that KAN and Bundo Kanduang do not have a clear and unsustainable work program, only activities in the form of ceremonies and formalities, as well as activities that depend on certain times. And it should also be a forum for community participation to be partners with the Nagari government, but only as a complement to the Panampuang Nagari Government because of the malfunctioning of that role.

In a different place, a confession from one of the board members from the Niniak Mamak element, realizing that he is an institution manager but does not know what to do in the institution, only invitations and meetings are held, if any. When in deliberations or meetings with the Nagari government, the management does not influence government policy, but instead only agrees/follows what has been directed and determined by 
the Nagari government. Meanwhile, the activities carried out in the village for the benefit of the community are carried out by the village government not through intermediaries for the Nagari social institutions, so that the influence is not felt in society

\section{CONCLUSION}

Organizational activities are the main factor in carrying out the roles of KAN and Bundo Kanduang, without organizational activities, KAN and Bundo Kanduang indirectly do not carry out their functions. The form of participation in the form of organizational activities is a requirement in carrying out institutional activities so that this form of participation is always carried out

\section{ACKNOWLEDGMENT}

In the process of this research, the authors would like to thank Research and Community Service Institute (LP2M) Universitas Negeri Padang for the assistance of PNBP research funds for the 2020 fiscal year. The author also thanks the Nagari Panampuang government and Nagari institutions and the Nagari Panampuang community who have supported research well, and thanks the research team for their cooperation and assistance. all parties, finally this research can be completed on time.

\section{REFERENCES}

[1] Azwar, W., Yunus, Y., Muliono, M., \& Permatasari, Y. (2018). Nagari Minangkabau. Jurnal Bina Praja: Journal of Home Affairs Governance, 10(2), 231-239.

[2] Djuharni, D. (2017). To interpret the values of Bundo Kanduang in the Internal Control System. The International Journal of Accounting and Business Society, 25(1), 81-90.

[3] Munir, M., \& Rumambo Pandin, M. G. (2020). The Values Of Bundo Kanduang Ethics In Indonesia. Talent Development \& Excellence, 12(1).

[4] Nelvi, Y. (2015). Peranan Kerapatan Adat Nagari (Kan) Dalam Pengalihan Tanah Ulayat Untuk Pembangunan Fasilitas Umum Dan Fasilitas Sosial (Fasum Dan Fasos) Di Pedesaan. Jurnal Agribisnis Kerakyatan, 5(1).

[5] Noer, M. (2006). Pembangunan berbasis kelembagaan adat: Sebuah alternatif pembelajaran dari kasus kinerja kelembagaan nagari dalam perencanaan wilayah di propinsi Sumatera Barat. MIMBAR: Jurnal Sosial dan
Pembangunan, 22(2), 235-258.

[6] Rizki, S. (2017). partisipasi politik masyarakat dalam pelaksanaan fungsi lembaga kemasyarakatan nagari (studi kasus nagari panampuang kecamatan ampek angkek) (Doctoral dissertation, Universitas Andalas).

[7] Rizaldi, S., Aromatica, D., Adrianto, A., Viona, J., Putri, A. A., \& Diana, I. D. (2019). Peran dan Hubungan Kerja Lembaga Kemasyarakatan dan Lembaga Adat di Nagari Lubuk Gadang Timur Kecamatan Sangir, Kabupaten Solok Selatan. Jurnal Warta Pengabdian Andalas, $26(4$. c).

[8] Rochaeti, N. (2019). The Existence of Kerapatan Adat Nagari in Minangkabau Community, West Sumatra for the Juvenile Criminal Justice System. In 6th International Conference on Community Development (ICCD 2019). Atlantis Press.

[9] Safitri, L., Malik, I., \& Marietta, J. R. (2018). Nagari Sebagai Pranata Penyelesaian Konflik: Suatu Kajian Tentang Kerapatan Adat Nagari (Kan) di Nagari Ketaping, Pariaman, Sumatra Barat. Jurnal Pertahanan \& Bela Negara,8(1), 125-148.

[10] Sari, L. P., Zetra, A., \& Valentina, T. R. (2020). Peran Ruang Publik Dalam Meningkatkan Pasrtisipasi Politik Di Nagari Talang Anau. Jurnal Niara, 13(2), 11-22.

[11] Syafira, Z. A., \& Putra, Y. Y. (2019). Persepsi Terhadap Kepemimpinan Transformasional Dengan Kepatuhan Pada Niniak Mamak Dan Bundo Kanduang. Jurnal Riset Psikologi, 2019(1).

[12] Syamsir, S. (2020). Competence, Job Satisfaction, Work Motivation, and Job Performance of The Village ("Nagari") Masters in Managing E-Village Finance. International Journal of Advanced Science and Technology, 29(8), 1337-1350.

[13] Widesma, A. V., \& Adnan, M. F. (2019). The Role Of Local Wisdom Values In The Implementation Of The Development Of Nagari Kamang Mudiak, Agam District, West Sumatera. JISPO Jurnal Ilmu Sosial dan Ilmu Politik, 9(2), 249-255.

[14] Yunarti, S. (2017). Pemberdayaan Lembaga Bundo Kanduang di Nagari Melalui Kebijakan Pembangunan yang Responsif Gender. Kafaah: Journal of Gender Studies, 7(2), 221-234.

[15] Yunus, Y. (2013). Aktor Kultural Dalam Pemerintahan Terendah Di Sumatera Barat (Posisi Ninik Mamak Dalam Struktural Adat dan Penyelenggaraan Pemerintahan Formal). Humanus, 12(1), 21-32. 